\title{
Screening of Alternaria Pathogens Associated with Parthenium hysterophorus for the Production of Lignocellulolytic Enzymes
}

\author{
Manpreet Kaur*, Neeraj Kumar Aggarwal \\ Department of Microbiology, Kurukshetra University, India
}

Copyright $(2017$ by authors, all rights reserved. Authors agree that this article remains permanently open access under the terms of the Creative Commons Attribution License 4.0 International License

\begin{abstract}
In the present investigation five pathogenic fungal isolates such as Alternaria alternata, Alternaria macrospora MKP2, Alternaria macrospora MKP4 Alternaria sp. PMK1 and Alternaria sp. PMK2, were isolated from diseased leaves of parthenium plant and found to be pathogenic to this weed. Isolated pathogens were screened qualitatively and quantitatively for lignocellulolytic activities. All the fungal pathogens were preliminary screened by qualitative assay and showed positive results by zone formation on respective agar plates. In quantitative assay all the isolates of Alternaria showed the production of one or the other lignocellulolytic enzymes. Enzymes of the pathogenic fungi are degraders of the polysaccharides available in the host plants and the strong enzymatic activities indicating the importance of the cell wall degrading enzymes in pathogenesis and potential of these pathogenic fungi to be used as biocontrol agent against parthenium weed.
\end{abstract}

Keywords Alternaria, Biocontrol, Lignocellulolytic, Parthenium, Pathogenic

\section{Introduction}

Parthenium hysterophorus L. (Asteraceae: Heliantheae), is considered as one of the most troublesome weeds, threatening natural and agricultural ecosystems by virtue of its high ecological amplitude and adaptability [1]. $P$. hysterophorus harbours a diversity of pathogenic fungi, as shown recently by Aggarwal et al [2]. Pathogenic fungi occupy a relatively unexplored area in microorganism enzymes with different potentialities. Plant biomass is made up of mostly polysaccharides. The plant cell wall is comprised of cellulose, hemicellulose, glycoproteins, pectin and lignin which makes up the structural framework of the wall [3]. Enzymes are involved in the initial entry of the pathogen, its spread within the plant tissue and the degradation of host tissue into metabolites, thus playing a fundamental role in host-parasite interaction [4]. Cellulose is the most abundant organic polysaccharide in the biosphere and major polysaccharide found in the plant cell wall, responsible for structural rigidity and strength to plants $[5,6]$. Cellulose is an unbranched glucose polymer composed of b-1,4-glucose units linked by a b-1,4-D glycosidic bond [7,8]. Plant pathogenic organisms have the ability to produce cellulase enzyme, that act to hydrolyze the b-1,4-D-glycosidic bonds within the cellulose molecules $[9,10]$. Lignin is an aromatic and heterogeneous constituent of plant cell wall that physically surrounds and protects the carbohydrate polymers from enzymatic hydrolysis and provides resistance towards microbial attack [11]. Therefore, accessibility and availability of the carbohydrate polymers and thereby effective use of lignin component depend on delignification of plant material [12]. The phytopathogenic organisms produce a variety of enzymes to degrade the complex polysaccharides of the plants. Cell wall degrading enzymes released by pathogens are known to be responsible for pathogenesis. The ability of a pathogen to produce lignocellulolytic enzymes determines the degree of degradation of cell wall during pathogenesis. In literature, the main studies on pathogenic fungi include screening for secondary metabolites (phytotoxins), but not many have explored the possibility for extracellular enzyme. During the survey it was observed that isolates of Alternaria infected the parthenium weed and caused leaf spot and leaf blight diseases. In virtue of the shortage of information about enzymatic activity of pathogenic fungi isolated from it, this present study evaluated the potential of five isolates of Alternaria fungi for lignocellulolytic enzyme production.

\section{Material and Methods}

\subsection{Isolation of Pathogens}

The fungal pathogens were isolated from the infected leaf 
portion of the parthenium weed. The leaves were cut into small portions and sterilized in 70 percent ethanol then washed in sterile distilled water for four to five times. Leaf portions were then placed on PDA medium plates supplemented with streptomycin sulphate. These were then incubated at $\pm 25^{\circ} \mathrm{C}$ for 7 days. Isolated fungi were aseptically transferred to PDA plates and the pure cultures were incubated at above conditions. The pure culture was maintained on PDA slants [2].

\subsection{Morphological Identification}

Lacto phenol cotton blue mount was used to study the morphological characteristics of the mycelium, conidia and perithecia of fungal strain and preliminarily identification was done with the help of standard literature $[13,14]$.

\subsection{Molecular Identification}

Fungal pathogen was molecular characterized by using the commercial service provided by Macrogen Inc., Advancing through Genomics, Korea. Fungus genomic DNA samples were extracted using a InstaGenetm Matrix (BIO-RAD.) The primers ITS1 primer (5- TCCGTAGGTGAACCTGCGG-3) and ITS5 (5-GGAAGTAAAAGTCGTAACAAGG-3) and ITS4 primer (5- TCCTCCGCTTATTGATATGC-3) were used for the PCR. The PCR reaction was performed with 20 ng of genomic DNA as the template in a $30 \mu l$ reaction mixture by using a EF-Taq (SolGent, Korea) as follows: activation of Taq polymerase at $95^{\circ} \mathrm{C}$ for 2 minutes, 35 cycles of $95^{\circ} \mathrm{C}$ for 1 minutes, $55^{\circ} \mathrm{C}$, and $72^{\circ} \mathrm{C}$ for 1 minutes each were performed, finishing with a 10-minute step at $72^{\circ} \mathrm{C}$. The amplification products were purified with a multiscreen filter plate (Millipore Corp., Bedford, MA, USA). The purified PCR products of approximately $600 \mathrm{bp}$ were sequenced by using 2 primers. Sequencing reaction was performed using a PRISM BigDye Terminator v3.1 Cycle sequencing Kit. The DNA samples containing the extension products were added to $\mathrm{Hi}-\mathrm{Di}$ formamide (Applied Biosystems, Foster City, CA). The mixture was incubated at $95^{\circ} \mathrm{C}$ for $5 \mathrm{~min}$, followed by 5 minutes on ice and then analyzed by ABI Prism 3730XL DNA analyzer (Applied Biosystems, Foster City, CA) [15].

\subsection{Pathogenicity Test}

The pathogenicity was determined in vitro conditions. Healthy leaves of parthenium were used for inoculation. The leaves were washed with sterile distilled water and wiped with a cotton swab dipped in $70 \%$ alcohol. Mycelial discs taken from 5 days old colony were placed on leaves. The inoculated leaves were kept in sterilized moist chambers and incubated at $25^{\circ} \mathrm{C}$. Regular observations were made for the appearance of symptoms after 3 days of incubation [16].

\subsection{Detection of Extracellular Lignocellulolytic Enzyme Production}

Five Alternaria isolates from Parthenium hysterophorus were screened qualitatively and quantitatively for Lignocellulolytic enzymes production. Action of lignin and cellulose degrading enzymes play an important role in bringing about degradation of lignin and cellulose present in biomass. Presence of these enzymes in pathogenic fungi helps in the pathogenesis by invasion of plant tissue.

\subsubsection{Qualitative Assay}

Qualitatively screening of fungal extracellular enzymes typically involves growth on specific indicative media.

\subsubsection{Cellulolytic Assay}

Glucose Yeast Extract Peptone Agar medium containing $0.5 \%$ Carboxy-methylcellulose was used for cellulase assay. After 3-5 days of fungal growth, the plates were flooded with $0.1 \%$ aqueous Congo red solution and de-stained with $1 \mathrm{M}$ $\mathrm{NaCl}$ for 15 minutes. Appearance of yellow areas around the fungal colony in an otherwise red medium indicated cellulase activity [17].

\subsubsection{Lignolytic Enzyme Assay}

Fungi degrade lignin by secreting enzymes collectively termed "ligninases". Ligninases can be classified as either phenol oxidases (laccase) or heme peroxidases (lignin peroxidase $(\mathrm{LiP})$, manganese peroxidase $(\mathrm{MnP})$.

\subsection{Azure-B Agar Assay for Lignin Peroxidase and Mn Peroxidase Enzymes}

One $\mathrm{cm}$ diameter plug cut from the growing edge of PDA cultures of selected isolates, was centrally inoculated on the surface of azure B agar plate [18]. The plates were incubated at $25 \pm 2{ }^{\circ} \mathrm{C}$ for 7 days. The uninoculated plate served as a control. The production of lignin peroxidase and $\mathrm{Mn}$ peroxidase was recorded as clearance of blue coloured medium.

\subsection{Guaiacol Agar Assay for Laccase Enzyme}

Laccase activity was assessed by growing the fungi on solid medium with guaiacol as indicator [19]. 0.01\% guaiacol was added to the solid medium (PDA) and incubated at $25^{\circ} \mathrm{C}$. Guaiacol positive reaction was indicated by the formation of a reddish brown halo under and around the fungal colonies (positive for guaiacol oxidation), indicating the presence of lignolytic enzymes (Laccase).

\subsubsection{Quantitative Assay}

\subsubsection{Media Formulation and Growth of Isolates for Enzyme Production}

Lignocellulolytic enzymes production in submerged cultures by the fungal strains was determined using parthenium collected from the Kurukshetra, Haryana. The parthenium plants were washed in distilled water, dried at $70^{\circ} \mathrm{C}$ in an oven and then pulverized using grinder. The pulverized samples were sieved through a mesh of $0.05 \mathrm{~mm}$ pore size to obtain a fine powder. Czapeck Dox broth (sodium nitrate $2 \mathrm{~g}$, potassium nitrate $1 \mathrm{~g}$, potassium chloride 
$0.5 \mathrm{~g}$, magnesium sulphate $0.5 \mathrm{~g}$, ferrous sulphate $0.01 \mathrm{~g}$, sucrose $30 \mathrm{~g}$ ) was formulated such that its sucrose was substituted with equivalent amount ( $30 \mathrm{~g} / \mathrm{L}$ of distilled water) of the parthenium as carbon source. Four mycelial plugs of 8 $\mathrm{mm}$ diameter from the tested fungi were grown in the formulated Czapeck Dox broth and incubated at $25^{\circ} \mathrm{C}$ for 15 days. After incubation pour the whole content of the flask containing the growing fungus through a funnel fitted with whatmann number 1 filter paper. Aliquots were centrifuged at $10,000 \mathrm{rpm}$ to obtain supernatant for enzyme assay. The filtrate contains the crude enzymes used for further studied [20].

\subsubsection{Cellulase Enzyme Assay}

Cellulase hydrolyzes carboxymethyl cellulose to produce free carboxymethyl glucose units. The free carboxymethyl glucose units react with 3-5 dinitrosalicylic acid (DNS) reagent to form a colored complex which is detected spectrophotometrically at $540 \mathrm{~nm}$ [21]. The cellulase activity was determined according to Zaldivar et al [9], using carboxymethylcellulose as substrate and the formation of reducing sugars was measured by reaction with dinitrosalicylic acid (DNS). The reaction mixtures containing $10 \mathrm{mg}$ CMC (Carboxymethyl cellulose) in $1 \mathrm{ml}$ of $0.05 \mathrm{M}$ sodium acetate buffer $(\mathrm{pH} 5.0)$ and $1 \mathrm{ml}$ culture supernatant were incubated at $50^{\circ} \mathrm{C}$ for $30 \mathrm{~min}$. The reducing sugar formed was measured with dinitrosalicyclic acid (DNS). One millilitre $(1 \mathrm{ml})$ of DNS reagent was added to 2 $\mathrm{ml}$ of the test sample. The colour was developed by boiling the mixture in water bath for $5 \mathrm{~min}$. Absorbance was read at $540 \mathrm{~nm}$ using spectrophotometer. Reducing sugar concentration was obtained from a standard glucose concentration curve. One unit of enzyme activity is defined as the amount of glucose $(\mu \mathrm{Mol})$ released per $\mathrm{mL}$ enzyme solution per minute.

\subsubsection{Azure B Assay for Lignin Peroxidase}

Azure B as a substrate to assay lignin peroxidase is commonly used by various researchers [18]. Reactions were carried out in $3 \mathrm{ml}$ cuvettes containing1 $\mathrm{ml}$ of $125 \mathrm{mM}$ sodium tartrate buffer ( $\mathrm{pH} 4.0), 500 \mu$ l of $0.160 \mathrm{mM}$ Azure B, $500 \mu \mathrm{l}$ of enzyme extract and $500 \mu \mathrm{l}$ of $2 \mathrm{mM} \mathrm{H}_{2} \mathrm{O}_{2}$. The optical density (OD) decrease was read at exactly $651 \mathrm{~nm}$.

\subsubsection{Manganese Peroxidase Assay}

Manganese peroxidise activity was assayed using $0.5 \mathrm{ml}$ of sodium tartrate buffer ( $\mathrm{pH} 5), 0.5 \mathrm{ml}$ of $100 \mu \mathrm{M}$ guaiacol, $1 \mathrm{ml}$ of distilled water, $0.1 \mathrm{ml}$ of culture filtrate, and $0.5 \mathrm{ml}$ of hydrogen peroxide $(30 \% \mathrm{w} / \mathrm{v})$ containing a reaction mixture and by reading its optical density at $465 \mathrm{~nm}$ [22].

\subsubsection{Guaiacol Assay Method for Laccase Assay}

Guaiacol has been reported as efficient substrate for laccase assay. The intense brown color development due to oxidation of guaiacol by laccase can be correlated to its activity often read at $450 \mathrm{~nm}$. Guaiacol $(2 \mathrm{mM})$ in sodium acetate buffer (10mM pH 5.0) was used as substrate. The reaction mixture contained $3 \mathrm{ml}$ acetate buffer, $1 \mathrm{ml}$ guaiacol and $1 \mathrm{ml}$ enzyme source and enzyme blank contained $1 \mathrm{ml}$ of distilled water instead of enzyme source. The mixture was incubated at $30^{\circ} \mathrm{C}$ for $15 \mathrm{~min}$ and absorbance was read at 450nm blank using UV spectrophotometer [23].

For these enzymes, 1 activity unit was defined as the amount of enzyme necessary to oxidize $1 \mu \mathrm{mol}$ substrate/min.

\section{Results}

During the extensive surveys conducted in the Kurukshetra district of Haryana in October 2013, the infestation of parthenium was recorded in crops, uncultivated areas and roadsides. A congress grass population was found affected by various leaf spots and leaf blight diseases at different parts of Kurukshetra. The infected part on PDA yielded a fungal pathogens and microscopic study revealed that the isolates belong to the genus Alternaria. The symptoms, cultural, morphological and molecular characteristics of the fungal isolates are described below.

\subsection{Alternaria alternata}

The symptoms appeared as small, central and marginal brown or black spots scattered on leaves. The spots became irregular in shape. When their size increased they turned brown to black in colour. Several such lesions may coalesce resulting in leaf drying. Culture grey green in colour with white margins is becoming black at maturity. Conidiophores light brown to golden brown, simple, branched, septate, straight or curved, smooth walled. Conidia light brown to olivaceous, borne long acropetal chains, ovoid or obclavate with a long or short beak, or ellipsoidal and without beak, smooth to echinulate, muriform with transverse and longitudinal septa. The beak, when present, is always smaller and lighter in colour than the conidial body (Figure 1). Diseased specimens and culture have been deposited at CAB International Mycological Institute, UK with reference No. 502784 and IIBC, Ascot, UK.

\subsection{Alternaria macrospora MKP2}

A pathogen was isolated on PDA media from infected leaves and it yielded grey colonies on PDA [16]. The morphological identification showed that mycelium was septate, hyaline and branched, conidia were solitary, dark brown, straight or slightly flexous, muriform and ellipsoidal with tapering long beak. The size of conidia ranged from 17.5-62.5×10-17.5 $\mu \mathrm{m}$ with 1-6 transverse septa and 0-2 longitudinal septa. Size of the beak ranged from 0-20×5-7.5 $\mu \mathrm{m}$. Chlamydospores numerous in nature and in culture, dark brown; a chlamydospore initially may be one-celled, intercalary or terminal on a hypha, round with a thickened wall but often including several adjacent cells on hypha, 
eventually cells dividing in several planes and chlamydospores becoming many celled and irregular in shape (Figure 2). The identification of the pathogen has been confirmed from the CABI International Mycological Institute, UK with reference No. 503549 and the results showed that the top matches at $100 \%$ identity to two sequences of Alternaria species, neither of which relate to published strains. Thereafter matches were only at $98 \%$ identity to various members of the genus, including $A$. macrospora, A. solani, A. dauci, A. crassa, A. porri and others. Molecular analysis of the ITS1-5.8S-ITS2 rDNA region was carried out to confirm the species identity of the pathogen. Fungal pathogen was molecular characterized by using the commercial service provided by Macrogen Inc., Advancing through Genomics, Korea. The molecular identification (ITS rDNA sequence analysis) showed the similarity of isolate with A. macrospora strain B isolated from Cotton plant infected with leaf blight disease. Sequence has been submitted to NCBI with GenBank accession number KM213867. In vitro pathogenicity of the isolated pathogen was determined and the typical disease symptoms were observed on leaves in lab. The inoculated pathogen was re-isolated, thus confirming the pathogenicity of $A$. macrospora to Parthenium hysterophorus and usual Koch's postulates.

\subsection{Alternaria macrospora MKP4}

Colonies are grey green in colour on PDA. The mycelium was septate, hyaline and branched. Conidia were solitary, dark brown, straight or slightly flexous, muriform and ellipsoidal with tapering long beak. The size of conidia ranged from $50-87.5 \times 7.5-17.5 \mu \mathrm{m}$ with 1-6 transverse septa and $0-3$ longitudinal septa. Size of the beak ranged from 7.5-75 $\times 2.5-7.5 \mu \mathrm{m}$ (Figure 3). The conidial morphology of Alternaria macrospora strain MKP4 is in agreement with those described by Ellis [13]. Culture has been identified from the Macrogen Inc., Advancing through Genomics, Korea and the sequence has been deposited to the NCBI gene bank with accession number KM514669. Koch postulates has been proven from in vitro pathogenicity test.

\subsection{Alternaria sp. PMK1}

Leaf spot yielded a greenish grey fungal colony with abundant aerial mycelium on PDA and PeDA [16]. The mycelium was septate, hyaline and branched. Conidia were solitary, rarely in chains of 2-3, dark brown, straight or slightly flexous, muriform with small beak. The size of conidia ranged from $12.5-42.5 \times 10-25 \mu \mathrm{m}$ with 1 to 8 transverse septa and 1 to 2 longitudinal septa, and 1 tangential septum. The conidial beak $(2-27.5 \times 5-10 \mu \mathrm{m})$ was pale brown, septate and swollen at the apex. Conidiophores are brown, straight to geniculate, up to $75 \mu \mathrm{m}$ long, $7.5 \mu \mathrm{m}$ thick and scar present at the point of bearing conidia (Figure 4). Based on these characteristics, the fungus was identified as Alternaria sp. [13]. The identification of the pathogen has been confirmed from CABI, International Mycological Institute, UK (IMI accession No. 504470) and Macrogen Inc., Advancing through Genomics, Korea. Molecular analysis of the ITS1-5.8S-ITS2 rDNA region carried out at CABI UK confirmed the pathogen as Alternaria sp.. Subsequently, however on submitting the pathogen isolate to Macrogen Inc., Korea sequence analysis doesn't show any similarity with published strains and the best match (99\%) was with unpublished strain of Alternaria alternata strain S-f6 (HM165489). The Sequence has been submitted to NCBI with GenBank accession number KT192437.

\subsection{Alternaria sp. PMK2}

Leaf spot yielded a dark grey fungal colony with abundant aerial mycelium on PDA. The mycelium was septate, hyaline and branched. Conidia were solitary, dark brown, straight or slightly flexous, muriform with tapering long, filiform, hyaline and septate beak. The size of conidia ranged from $62.5-120 \times 10-25 \mu \mathrm{m}$ with 3 to 9 transverse septa and 2 to 5 longitudinal septa. Size of the beak ranged from 25-127.5 x 5-7.5 $\mu \mathrm{m}$ sometimes swollen at the apex, often much longer than the body of the conidia. The conidial morphology of Alternaria sp. PMK2 is in agreement with those described by Ellis [13]. Conidiophores are dark brown, straight to geniculate, arises in clusters, scar present at the point of bearing conidia (Figure 5). Based on these characteristics, the fungus was identified as Alternaria sp. The identification of the pathogen has confirmed from CABI, International Mycological Institute, UK (IMI accession No. 504469) and Macrogen Inc., Advancing through Genomics, Korea as Alternaria sp. PMK2. The Sequence has submitted to NCBI with accession number KT192438.

\subsection{Production of Cell Wall Degrading Enzymes}

The use of simpler solid media permits the rapid screening of large populations of fungi for the presence or absence of specific enzymes. The five pathogenic Alternaria fungi were isolated from parthenium plants. All isolates were sub cultured routinely and maintained in the department. The isolates of filamentous fungi were screened for production of cellulase, laccase, manganese peroxidase and lignin peroxidase enzymes qualitatively, on agar media containing specific substrates and quantitatively in liquid medium containing parthenium as substrate. Each isolate was able to produce one or the other lignocellulolytic enzymes, some of the pathogens were able to produce all lignocellulolytic enzymes.

\subsubsection{Qualitative Assay}

\subsubsection{Cellulase}

Five pathogenic Alternaria species were checked for cellulase activity qualitatively by dye diffusion method. In this assay after growth of the fungus on CMC, a dye is used to differentiate between intact $\mathrm{CMC}$ and degraded substrate. 
CMC degradation around the colonies appears as a yellow-opaque area against a red colour for un-degraded CMC. Zone production by all the tested fungi indicates the presence of cellulase enzyme. The activity is checked on the earlier stages of culture growth, when it was just five days old. The prominent zone of yellow opaque area in the cellulase activity was observed on the fourth to sixth day of the mycelial growth on Petri plate. Appearance of halo areas around the fungal colony in an otherwise red medium indicated the cellulase activity. The formation of such zone was constant from sixth day till the maturation of mycelium (Figure 6).

\subsubsection{Laccase (Guaiacol oxidation)}

Guaiacol oxidation is one of the most convenient qualitative assays for Ligninolytic enzyme production among fungi. Five pathogenic fungal isolates of parthenium were screened for guaiacol oxidation and radial growth rate on agar plates containing guaiacol as an aromatic model compound. Results showed that all the fungal isolated from parthenium exhibited an ability to oxidize guaiacol, halo of intense brown colour was formed under and around the fungal colonies (positive for guaiacol oxidation), indicating the presence of ligninolytic enzymes (Laccase) Figure 7.

\subsubsection{Lignin Peroxidase (Lip) and Manganese Peroxidase} (Mnp)

Decolourization of the dye Azure-B by fungi has been positively correlated with production of lignin peroxidase and Manganese peroxidase. In solid plate screening all the five Alternaria pathogens decolorized the Azure B dye and exhibited an ability of producing lignin peroxidase and Manganese peroxidase enzymes. The results of Azure B dye degradation on solid medium are depicted in Figure 8.

\subsubsection{Quantitative Enzymatic}

\subsubsection{Cellulolytic Activity}

For successful pathogenesis, the pathogen has to overcome the host barriers like cell wall, pectin layer and protein matrix [24]. In the present work we have shown that the fungal pathogens isolated from parthenium produces cellulase enzyme necessary to degrade important structural cell wall polysaccharides, particularly cellulose and hemicellulose (Table 1). The secretion of this enzyme provides these pathogenic fungi with the ability to attack host. All isolates of Alternaria were capable of producing cellulase in submerged cultures containing parthenium as carbon source. In quantitative estimation, after 10 days, Alternaria sp. PMK2 $(1.7 \mathrm{U} / \mathrm{ml} / \mathrm{min})$ produced maximum cellulase activity while other isolates such as Alternaria sp. PMK1, Alternaria macrospora MKP2, Alternaria macrospora MKP4 and Alternaria alternata exhibited 0.97 , $0.7,0.7$ and $0.64 \mathrm{U} / \mathrm{ml} / \mathrm{min}$ respectively (Table 1 ). The results obtained in the present study indicate that the activity of cellulase enzyme increased with increase of the culture age and maximum activity was recorded after 10 days. Mycelial dry weight also increased with the increase of incubation period. However, these enzymes were better induced in Alternaria sp. PMK1 and Alternaria sp. PMK2 as compared to Alternaria macrospora MKP2 and Alternaria macrospora MKP4 Table 1. The enzymes produced by these fungal pathogens may be seen as pathogenic in the penetration of the plant material.

\subsubsection{Lignolytic Activity}

In view of the results obtained, the production of main ligninolytic enzymes ( $\mathrm{LiP}, \mathrm{MnP}$ and laccase), was studied in liquid media using parthenium as substrate for 20 days. An aliquot of sample was aseptically removed at three days interval and assayed for the enzymes LiP, MnP and laccase by the methods described in enzyme assays. The result showed that, laccase and lignin peroxidase enzymes were detected in all the five isolates. Manganese peroxidase was absent in one of the isolate i.e. Alternaria sp. PMK1 while other four isolates were found to be positive for MnP enzyme (Table 1).

The enzyme activity was measured every day after the third day of incubation and continued until decrease in activity level was observed. The laccase enzyme activity was high on the 15th day of incubation and Alternaria sp. PMK2 expressed a high titer $(26.50 \mathrm{U} / \mathrm{ml})$ of laccase on 15 th day of incubation followed by Alternaria alternata $(11.61 \mathrm{U} / \mathrm{ml})>$ Alternaria macrospora MKP4 (3.77U/ml), Alternaria macrospora MKP2 $(2.67 \mathrm{U} / \mathrm{ml})$ and the least laccase activity was observed in Alternaria sp. PMK1 $(2.0 \mathrm{U} / \mathrm{ml})$. The lignin peroxidase enzyme production started on $6^{\text {th }}$ day of incubation and highest activity was recorded on $10^{\text {th }}$ day of incubation. Out of the five isolates Alternaria macrospora MKP2 and Alternaria alternata highest LiP activity i.e. $0.25 \mathrm{U} / \mathrm{ml}$ and $0.23 \mathrm{U} / \mathrm{ml}$ respectively, least LiP enzyme activity was recorded in Alternaria macrospora MKP4 (0.16U/ml). Alternaria sp. PMK1 and Alternaria sp. PMK2 produced LiP in same range of $0.19(\mathrm{U} / \mathrm{ml})$. MnP production was started on $15^{\text {th }}$ day of incubation and the highest activity was also recorded on $15^{\text {th }}$ day of incubation and after that the decrease occurred in enzymatic activity. The highest enzymatic activity was recorded in Alternaria sp. PMK2 $(0.3 \mathrm{U} / \mathrm{ml})$ followed by Alternaria alternata $(0.25 \mathrm{U} / \mathrm{ml})>$ Alternaria macrospora MKP4 $(0.144 \mathrm{U} / \mathrm{ml})$ and Alternaria macrospora MKP2 $(0.12 \mathrm{U} / \mathrm{ml})$. This activity was absent in Alternaria sp. PMK1. The Ligninolytic enzymes produced by these fungal pathogens may be seen as pathogenic in the penetration of the parthenium plant material and could to be useful in biocontrol of parthenium weed. 


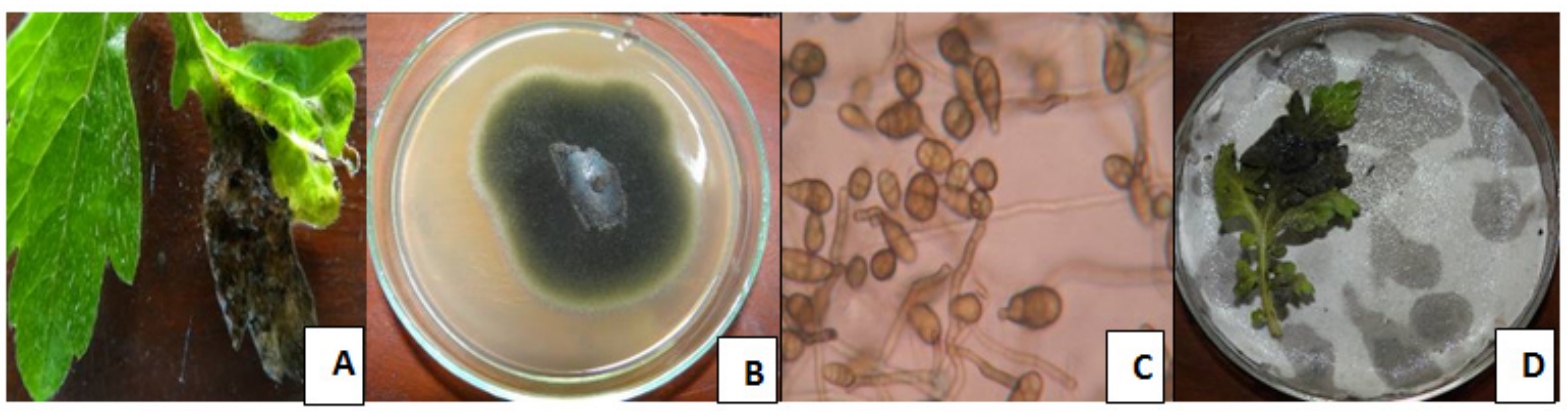

Figure 1. Alternaria alternata:- (A) symptoms of the pathogen on the leaf of parthenium; (B) Colony of the pathogen after 5 days at $25^{\circ} \mathrm{C}$ on $\mathrm{PDA}$; (C) conidia; (D) Infection on leave in vitro condition.

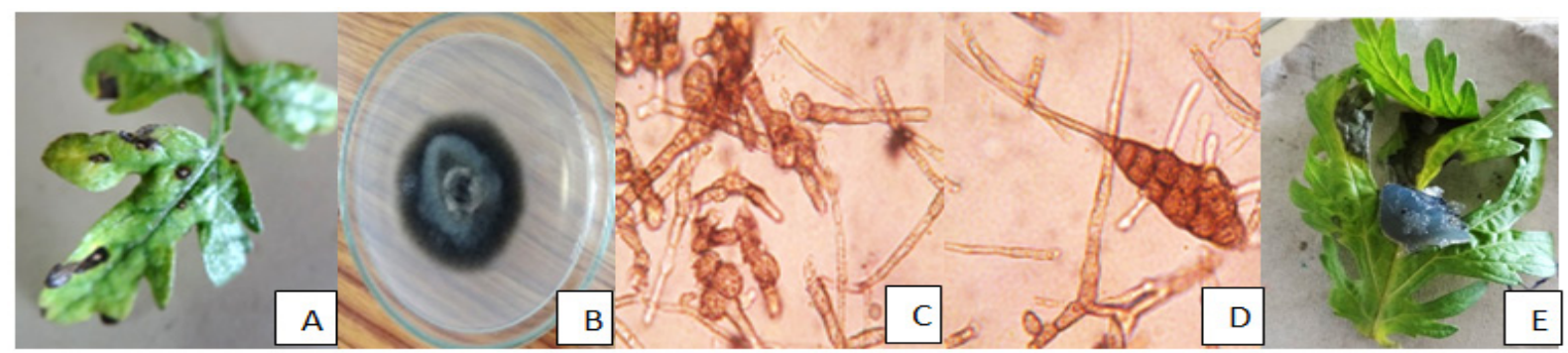

Figure 2. Alternaria macrospora strain MKP1:- (A) symptoms of the pathogen on the leaf of parthenium; (B) Colony of the pathogen after 5 days at $25^{\circ} \mathrm{C}$ on PDA; (C) Chlamydospores (D) conidia with conidiophore; (E) Infection on leave in vitro condition

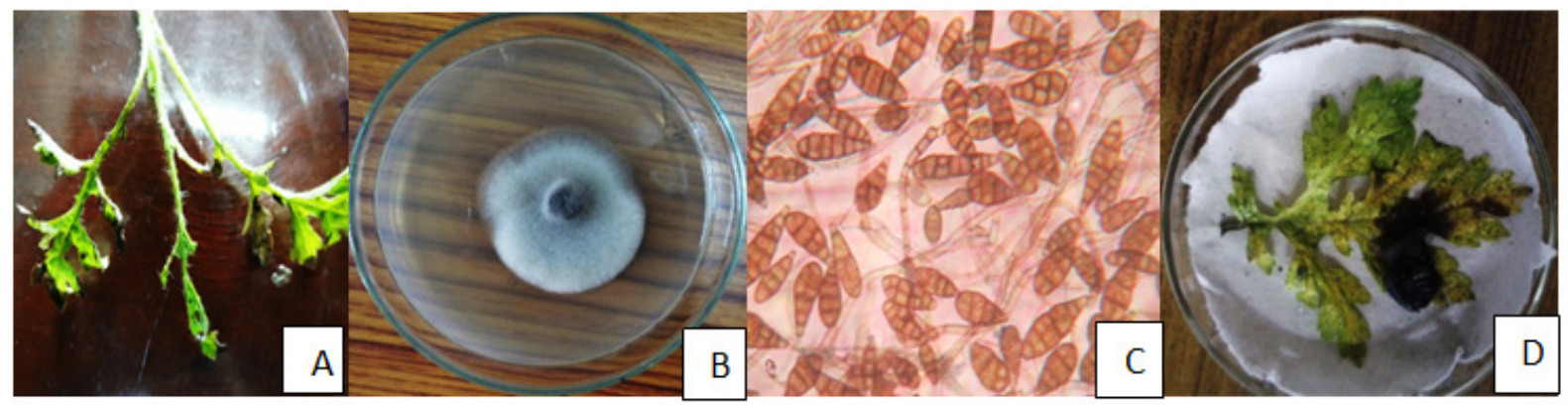

Figure 3. Alternaria macrospora strain MKP4:- (A) symptoms of the pathogen on the leaf of parthenium; (B) Colony of the pathogen after 5 days at $25^{\circ} \mathrm{C}$ on PDA; (C) conidia; (D) Infection on leave in vitro condition.

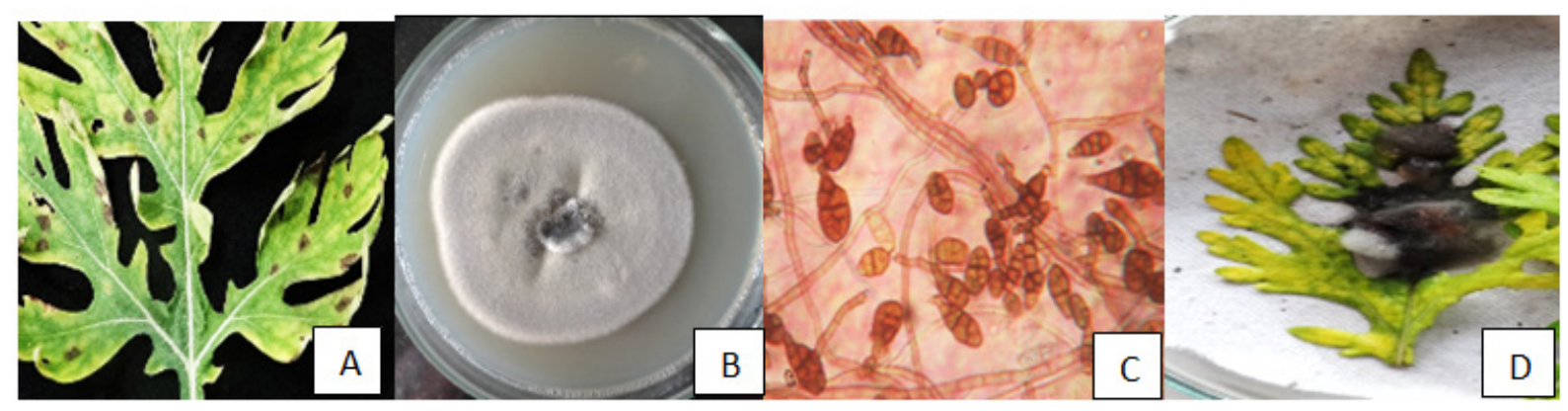

Figure 4. Alternaria sp. PMK1:- (A) Leaf spot of Parthenium hysterophorus caused by Alternaria sp. PMK1; (B) Growth of fungus isolated from symptomatic leaf on PDA media; (C) Conidia of Alternaria sp. PMK1 at $40 \mathrm{X}$ in light microscope; (D) In-vitro pathogenicity 


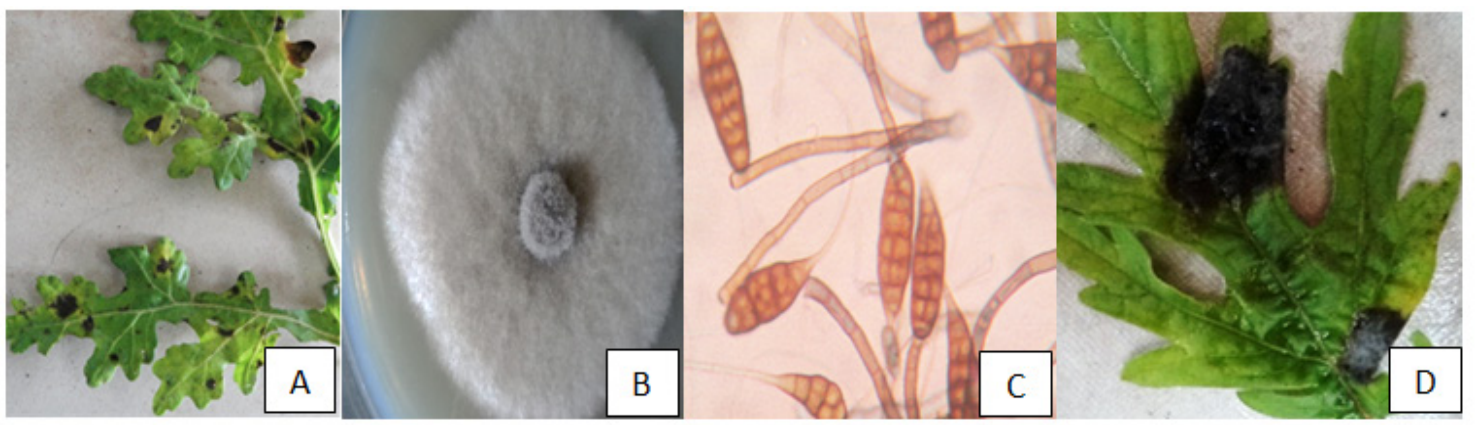

Figure 5. (A) Leaf spot of Parthenium hysterophorus caused by Alternaria sp. PMK2; (B) Growth of fungus isolated from symptomatic leaf on PDA media; (C) Conidia and conidiophores of Alternaria sp. PMK2 at $40 \mathrm{X}$ in light microscope; (D) In-vitro pathogenicity

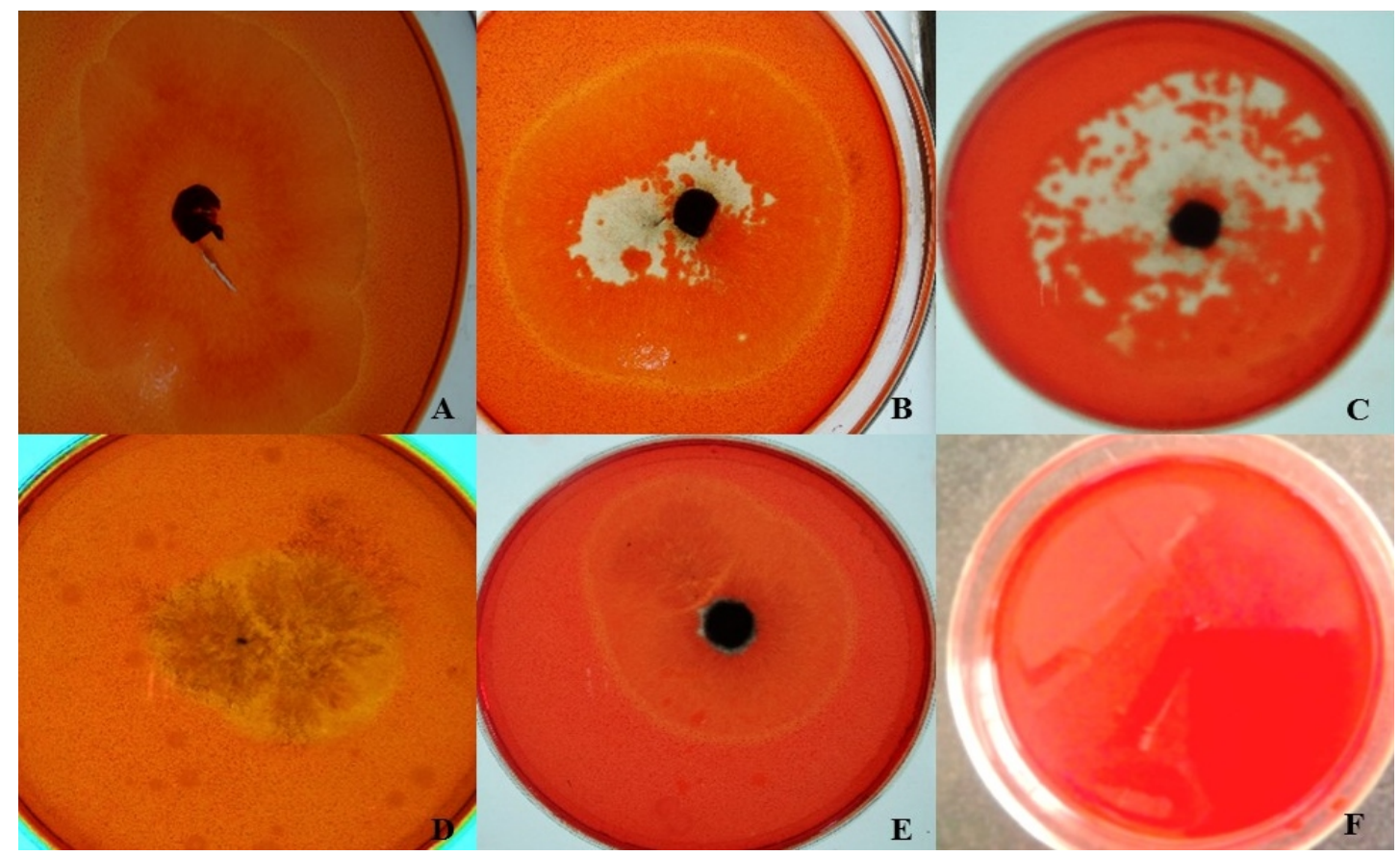

Figure 6. Cellulase activity on CMC Agar media; (A) Alternaria alternata; (B) Alternaria macrospora MKP2; (C) Alternaria macrospora MKP4; (D) Alternaria sp. PMK1; (E) Alternaria sp. PMK2; (F) Control

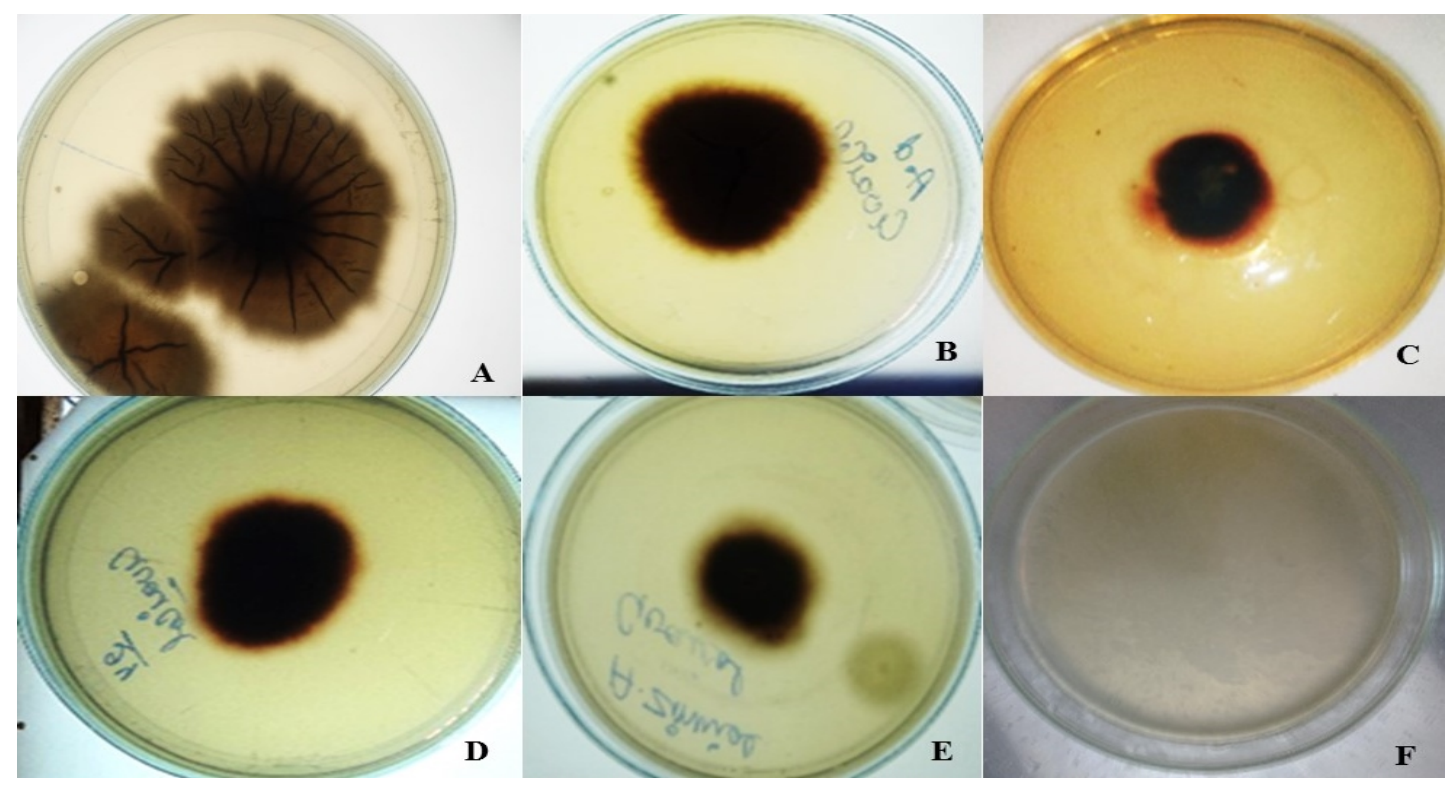

Figure 7. Laccase activity on Guaiacol Agar media; (A) Alternaria alternata; (B) Alternaria macrospora MKP2; (C) Alternaria macrospora MKP4; (D) Alternaria sp. PMK1; (E) Alternaria sp. PMK2 (F) Control 


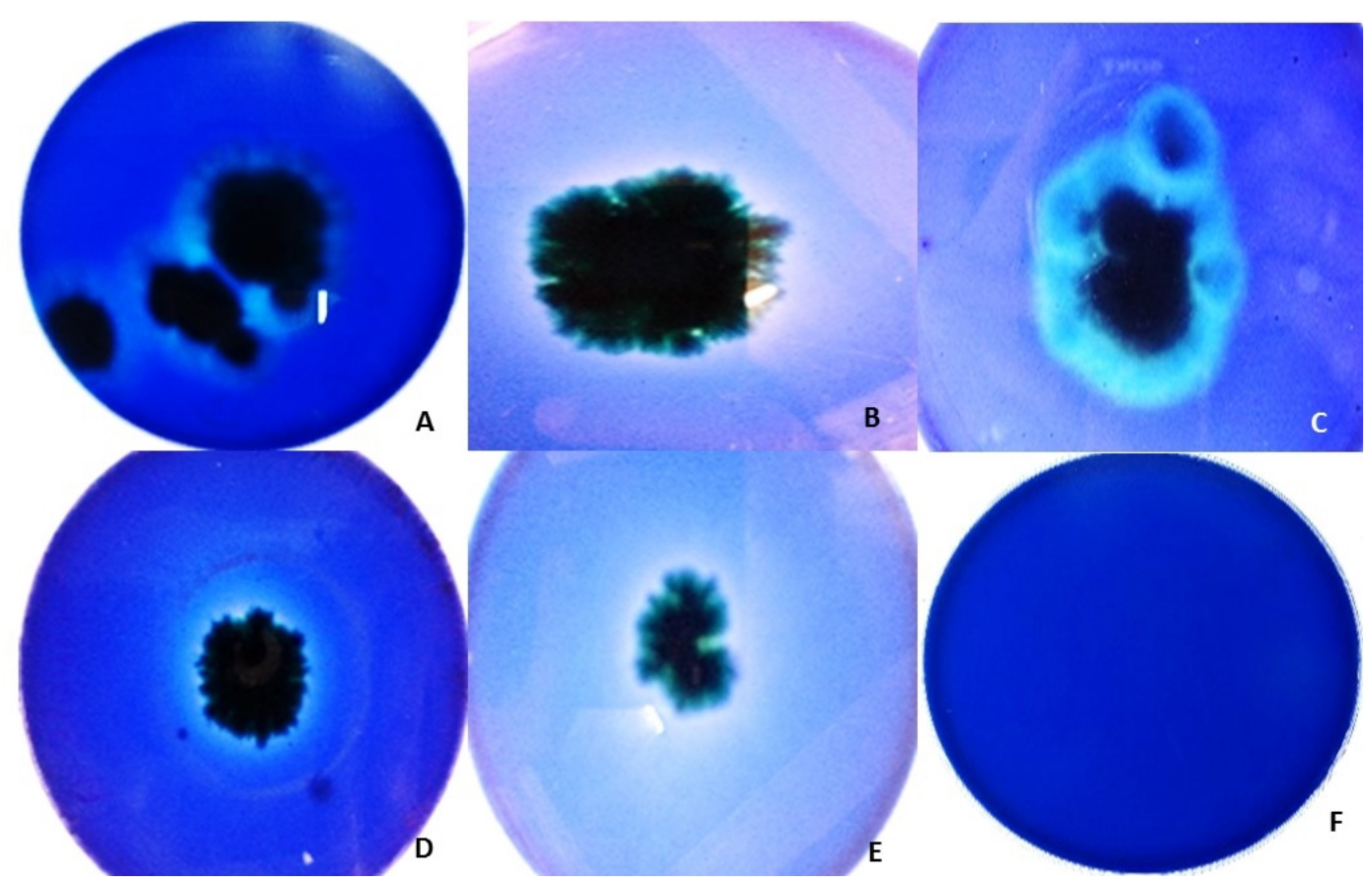

Figure 8. LiP and MnP activity on Azure B Agar media; (A) Alternaria alternata; (B) Alternaria macrospora MKP2; (C) Alternaria macrospora MKP4; (D) Alternaria sp. PMK1; (E) Alternaria sp. PMK2 (F) Control

Table 1. Cellulase, LiP, MnP and Laccase activities of the isolated pathogens screened in liquid cultures containing parthenium as substrate.

\begin{tabular}{|c|c|c|c|c|}
\hline Isolates & $\begin{array}{c}\text { Cellulase } \\
(\mathrm{U} / \mathrm{ml})\end{array}$ & $\begin{array}{c}\mathrm{LiP} \\
(\mathrm{U} / \mathrm{ml})\end{array}$ & $\begin{array}{c}\mathrm{MnP} \\
(\mathrm{U} / \mathrm{ml})\end{array}$ & $\begin{array}{c}\text { Laccase } \\
(\mathrm{U} / \mathrm{ml})\end{array}$ \\
\hline Alternaria alternata & $\begin{array}{c}0.64^{*} \pm \\
0.02^{* * \mathrm{cw}}\end{array}$ & $0.23 \pm \pm 0.09^{\mathrm{cx}}$ & $0.25 \pm 0.21^{\mathrm{cy}}$ & $11.61 \pm 0.07^{\mathrm{cz}}$ \\
\hline Alternaria macrospora MKP2 & $0.7 \pm 0.10^{\mathrm{ew}}$ & $0.25 \pm 0.035^{\mathrm{ex}}$ & $0.12 \pm 0.15^{\mathrm{ey}}$ & $2.67 \pm 0.14^{\mathrm{ez}}$ \\
\hline Alternaria macrospora MKP4 & $0.7 \pm 0.05^{\mathrm{dw}}$ & $0.16 \pm 0.25^{\mathrm{dx}}$ & $0.144 \pm 0.05^{\mathrm{dy}}$ & $3.77 \pm 0.05^{\mathrm{dz}}$ \\
\hline Alternaria sp. PMK1 & $0.97 \pm 0.01^{\mathrm{bw}}$ & $0.19 \pm 0.16^{\mathrm{bx}}$ & - & $2.0 \pm 0.06^{\mathrm{bz}}$ \\
\hline Alternaria sp. PMK2 & $1.7 \pm 0.32^{\mathrm{aw}}$ & $0.19 \pm 0.52^{\mathrm{ax}}$ & $0.3 \pm 0.03^{\mathrm{ay}}$ & $26.50 \pm 0.15^{\mathrm{az}}$ \\
\hline
\end{tabular}

*-Values, including are means of three replicates; **-Standard deviation; Values with different letters show significant difference $(\mathrm{P} \leq 0.05)$ as determined by Tukey's HSD test.

\section{Discussion}

In the present study, the fungal pathogens of parthenium weed were screened for lignocellulolytic enzyme production. The elaboration of an array of cell wall splitting enzymes helps the pathogen for easy penetration of the host cell wall and subsequent colonization [25]. The results obtained in the present study indicate that all the five isolates of Alternaria produced lignocellulolytic enzymes. The activity of cellulase enzyme increased with increase of the incubation time and reached to maximum after 10 days. Alternaria sp. PMK1 and Alternaria sp. PMK2 of Alternaria produced more cellulase than the Alternaria macrospora MKP2, Alternaria macrospora MKP1 and Alternaria alternata. Walch and Khulwein [26] also reported that Ganoderma resinaceum and G. pfeifferi produced extracellular enzymes which degraded CMC and cellulose. Muthulakshmi [27] also found that $A$. tenuis produced cellulase enzyme which degraded cellulose. All these cell wall splitting enzymes are mostly adaptive, secreted by the pathogen in the presence of appropriate substrates. The production and activity of cellulolytic enzymes detected using parthenium as substrate suggest their active role in disease development by the pathogen in parthenium. Since all the species of Alternaria are intercellular in the host, the productions of these enzymes appears to facilitate the dissolution of host cell wall and middle lamella and help entry and establishment of the pathogen in the host and are possibly responsible for playing a vital role in pathogenesis through cell wall degradation and disintegration of tissues. Lignin found in middle lamella, secondary cell wall of xylem vessels and the fibres that strengthen the plants. In fungi Ligninolytic enzymes probably have more roles in fungal plant-pathogen/host interaction and stress defence and lignin degradation [28]. Only a small group of microorganisms are capable of degrading lignin as the lignin is more resistant to enzymatic degradation than other plant substances. Most of the ligninolytic enzymes reported thus far are of fungal origin, especially from white rot fungi but some pathogenic ascomycetes and deuteromycetes are also known to produce lignin degrading enzymes [29]. A numbers of cell wall degrading enzymes have been shown to be produced by plant 
pathogens [25], which are known to facilitate cell wall penetration and tissue maceration in host plants. Since all the species of Alternaria are intercellular in the host, the productions of these enzymes appears to facilitate the dissolution of host cell wall and middle lamella and help entry and establishment of the pathogen in the host and are possibly responsible for playing a vital role in pathogenesis through cell wall degradation and disintegration of tissues [30]. In the present study, the virulent pathogens isolated from parthenium weed produced lignocellulolytic enzymes using parthenium as carbon source, indicating the importance of the cell wall degrading enzymes in pathogenesis against parthenium weed. This study will serve to understanding the role of lignocellulolytic enzymes in pathogenicity against parthenium weed.

\section{Conclusions}

In the present work pathogenic fungal species from parthenium, producing lignocellulolytic enzymes were documented. These fungal isolates of Alternaria are reported for the first time as the efficient producers of Lignocellulolytic enzymes. The excellent enzymatic activity and pathogenesis of these isolates accentuates their potential in biocontrol of devastating weed parthenium.

\section{Acknowledgments}

The authors are thankful to the University Grants Commission, New Delhi for providing financial assistance in the form of Maulana Azad National Fellowship for minority students.

\section{REFERENCES}

[1] M. Kaur, N. K. Aggarwal, V. Kumar, R. Dhiman. Effects and Management of Parthenium hysterophorus a weed of global significances, International Scholarly Research Notices, doi.org/10.1155/2014/368647, 2014.

[2] N. K. Aggarwal, M. Kaur, V. Kumar, A. Saini. Mycobiota associated with Parthenium hysterophorus isolated from North India, Indian Journal of Weed Science, vol. 46, pp. $155-160,2014$.

[3] G.N. Agrios. Plant Pathology, 5th ed, Elsevier Academic Press, San Francisco, 2005.

[4] P. Sarkar. Elena Bosneaga1 and Manfred Auer Plant cell walls throughout evolution: towards a molecular understanding of their design principles, Journal of Experimental Botany, vol. 60, no. 13, pp. 3615-3635, 2009.

[5] T. Murai, M. Ueda, T. Kavaguchi, M. Arai, M. Tanaka. Assimilation of cellooligosaccharides by a cell surface engineered yeast expressing $\beta$-glucosidase and carboxymethylcellulase from Aspergillus aculeatus. Applied and Environmental Microbiology. Vol. 64, pp. 4857-4861, 19998.

[6] J. Hong, H. Tamaki, S. Akiba, K. Yamamoto, H. Kumaga. Cloning of a gene encoding a highly stable endo- $\beta-1$, 4-glucanase from Aspergillus niger and its expression in yeast. Journal of Bioscience and Bioengineering. Vol. 92, pp. 434-441, 2001

[7] M.M.C. Gielkens, E. Dekkers, J. Visser, L.H. Graaff. Two cellubiohydrolase-encoding genes from Aspergillus niger require D-xylose and the xylanolytic transcriptional activator XlnR for their expression. Applied and Environmental Microbiology. Vol. 65, pp. 4340-4345, 1999.

[8] S.J. Han, Y.J. Yoo, H.S. Kang. Characterization of a bifunctional cellulase and its structural gene. The cell gene of Bacillus sp. D04 has exo- and endoglucanase activity. The Journal of Biological Chemistry. Vol. 270, pp. 26012-26019, 1995.

[9] M. Zaldivar, J.C. Velasquez, I. Contreras, L.M. Perez. Trichoderma aueviride 7-121, a mutant with enhanced production of lytic enzymes; its potential use in waste cellulose degradation and/or biocontrol. Electronic Journal of Biotechnology. pp. 1-7, 2001.

[10] F.G. Moreira, R. Simon, M.A.F. Costa, S.C.G. Marques de, R.M. Peralta. Production of hydrolytic enzymes by the plant pathogenic fungus Myrothecium verrucaria in submerged cultures. Brazilian Journal of Microbiology. Vol. 36, pp.7-11, 2005.

[11] M. Narkhede, R, Mahajan, K. Narkhede. Ligninolytic enzyme production and remazol brilliant blue $\mathrm{r}$ (rbbr) decolorization by a newly isolated white rot fungus basidiomycota. SPP. L-168, International Journal of Pharma and BioSciences, vol. 4, no. 1, pp. 220-228, 2013.

[12] J. Rytioja, K. Hildén, J. Yuzon, A. Hatakka, R. P. de Vries, M. R. Makela. Plant-Polysaccharide-Degrading Enzymes from Basidiomycetes, Microbiology and Molecular Biology Reviews, vol. 78, no. 4, pp. 614-649, 2014.

[13] M. B. Ellis. Dematiaceous Hyphomycetes, Commonwealth Mycological Institute, England, 1971.

[14] M. B. Ellis. More Dematiaceous Hyphomycetes, Commonwealth Mycological Institute, England, 1976.

[15] M. Satou, M. Ichinoe, F. Fukumoto, N. Tezuka, S. Horiuchi. Fusarium Blight of Kangaroo Paw (Anigozanthos spp.) caused by Fusarium chlamydosporum and Fusarium semitectum, Journal of Phytopathology, vol. 149, pp. 203-206, 2001.

[16] K. R. Aneja, S. A. Khan, S. Kaushal. Management of Horse purslane (Trianthema portulacastrum L.) with Gibbago trianthemae Simmons in India. In: Proceedings of the X International Symposium on Biological Control of Weeds, Montana State University, Bozeman, Montana, pp. 27-33, 2000 .

[17] V.H. Sunitha, D. Nirmala, C. Srinivas. Extracellular Enzymatic Activity of Endophytic Fungal Strains Isolated from Medicinal Plants. World Journal of Agricultural Science. Vol. 9. pp. 01-09, 2013.

[18] F.S. Archibald. A new assay for lignin-type peroxidase employing the dye Azure B. Applied and Environmental Microbiology. Vol. 58(31), pp. 6-10, 1992. 
[19] L.L. Kiiskinen, M. Ratto, K. Kruus. Screening for novel laccase-producing microbes Journal of Applied Microbiology. Vol. 97, pp. 640-646, 2004.

[20] Y. Ahmad, A. Hameed, A. Ghaffar. Enzymatic Activity of Fungal Pathogens in Corn. Pakistan Journal of Botany. Vol. 38: 4, pp. 1305-1316, 2006.

[21] N.J. Gadgil, H.F. Daginawala, T. Chakrabarti, P. Khanna. Enhanced cellulase production by a mutant of Trichoderma reesei. Enzyme and Microbial Technology. Vol. 17, pp. 942-946, 1995.

[22] A. Parzeznski, V.B. Hynn, R.L. Crawford. Comparison of lignin I and peroxidase M2 from the white rot fungus Phanerochete chrysosporium. Annual Review of Physical Chemistry. Vol. 244, pp. 750-765, 1986.

[23] A. Jhadav, K. K. Vamsi, Y. Khairnar, A. Boraste, N. Gupta.Optimization of production and partial purification of laccase by Phanerochaete chrysosporium using submerged fermentation, International Journal of Microbiology Research, vol. 1, pp. 09-12, 2009. C. F.

[24] P.H. Williams, R. Heitefuss, Physiological Plant Pathology,
(Springer Verlag, Berlin), 1976, 306.

[25] Y. Chenglin, S. C. William, E. S. Carl. Purification and characterization of a polygalacturanase produced by Penicillium expansum in apple fruit, Phytopathology, vol. 86, pp. 1160-1166, 1996.

[26] H. Walch, H. Khulwein. On cellulolytic activity in the genus Ganoderma. Archives of Microbiology. Vol. 61, pp. 373-380, 1968.

[27] P. Muthulakshmi, Studies on fruit rot of chilli (Capsicum annuum L.) caused by Alternaria tenuis Nees. M.Sc. (Ag.). Thesis, Tamil Nadu Agric. Univ., Madurai, India, 1990, 139.

[28] Thurston. The structure and function of fungal laccases, Microbiology, vol. 140, pp. 19-26, 1994.

[29] P.D. Sharma. Plant Pathology. 2nd ed., Rastogi Publications, India, 2008.

[30] T. Anand, R. Bhaskaran, T. Raguchander, G. Karthikeyan, M. Rajesh, G. Senthilraja. Production of cell wall degrading enzymes and toxins by Colletotrichum capsici and Alternaria alternata causing fruit rot of chillies, Journal of Plant Protection Research, vol. 48 no. 4, pp. 437-451, 2008. 